\title{
Transcriptomics in a high throughput world
}

\author{
Chad Nusbaum
}

From Beyond the Genome: The true gene count, human evolution and disease genomics Boston, MA, USA. 11-13 October 2010

Sequencing-based approaches are transforming our ability to investigate, interpret and define transcriptomes, which comprise the expressed elements in genomes. This is driven by innovations in all steps in the process, including sample preparation, cDNA library construction, increases in sequencing data yield and development of new computational approaches. I will describe the state of the art in the field as well as new approaches and results from current work in transcriptome analysis at the Broad Institute.

Published: 11 October 2010

doi:10.1186/gb-2010-11-S1-I12

Cite this article as: Nusbaum: Transcriptomics in a high throughput

world. Genome Biology 2010 11(Suppl 1):I12.
Genome Sequencing and Analysis Program, Broad Institute, Cambridge MA 02141, USA
Submit your next manuscript to BioMed Central and take full advantage of:

- Convenient online submission

- Thorough peer review

- No space constraints or color figure charges

- Immediate publication on acceptance

- Inclusion in PubMed, CAS, Scopus and Google Scholar

- Research which is freely available for redistribution

Submit your manuscript at www.biomedcentral.com/submit
C Biomed Central 